\title{
СИНТЕЗ КОНЬЮГАТОВ ПОЛИЭДРИЧЕСКИХ ГИДРИДОВ БОРА С ХОЛЕСТЕРИНОМ И КУРКУМИНОМ ДЛЯ ПОТЕНЦИАЛЬНОГО ИСПОЛЬЗОВАНИЯ ИХ В БОР-НЕЙТРОНОЗАХВАТНОЙ ТЕРАПИИ РАКА
}

\author{
А.А.Друзина, В.И. Брегадзе \\ Лаборатория алюминий- и борорганических соединений, \\ Институт элементоорганических соединений им. А.Н. Несмеянова РАН, \\ 119991, Россия, Москва, ул. Вавилова, д.28.
}

DOI: 10.19163/MedChemRussia2021-2021-232

E-mail: ilinova_anna@mail.ru

Создание биологических наномолекул, содержащих большое количество атомов бора и способных селективно накапливаться в раковых клетках, является одним из ключевых требований бор-нейтронозахватной терапии (БНЗТ) рака. Борсодержащие производные холестерина и куркумина могут быть пригодными для потенциального использования в БНЗТ опухолей как в качестве самостоятельных агентов, так и в составе липосом, которые являются хорошим транспортом для селективного накопления соединений в опухоли. Введение терапевтических агентов в водную фазу и/или оболочку липосом является инновационным высокотехнологичным подходом, позволяющим увеличить биодоступность за счет пассивного нацеливания, а также снизить риск возникновения побочных эффектов [1]. Таким образом, разработаны подходы к синтезу конъюгатов бис(дикарболлида) кобальта с куркумином, а также липофильных производных холестерина с нидо-карбораном, которые могут быть использованы в дизайне частиц липосомальной природы [2].
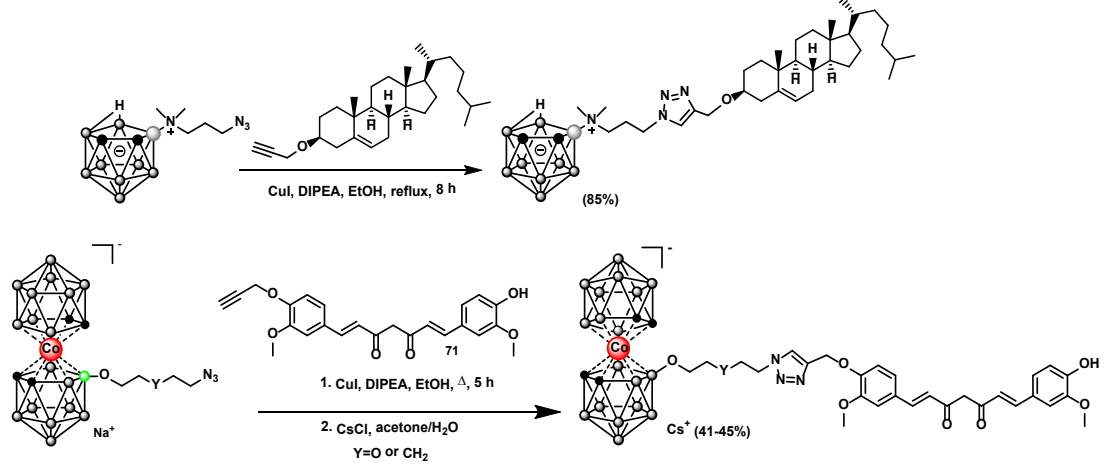

Работа выполнена при поддержке Российского научного фонда

(грант № 20-73-00228)

\section{Литература}

[1] G. Terstappen, R. Roncarati, J. Dunlop and R. Peri, Future Med. Chem. 2010, 5, 715-730.

[2] A. Druzina, O. Zhidkova, N. Dudarova, I. Kosenko, I. Ananyev, S. Timofeev and V. Bregadze, Molecules, 2021, 26, 530-545. 